\title{
Two new species of Neomachilellus Wygodzinsky (Meinertellidae, Microcoryphia) from the state of Amazonas, Brazil
}

\author{
Pedro Wygodzinsky (*)
}

\begin{abstract}
Two new species of Microcoryphia, Neomachilellus adisi and $\mathbf{N}$. scandens, occurring in the inundation forests near Manaus and collected in tree-traps, are described and compared to other species of the genus.

The present paper contains the descriptions of two new species of the large, mainly neotropical machilid genus Neomachilellus Wygodzinsky, with the purpose of making their names available for ecosystem analyses now being carried out by Adis (1977) in the inundation forests near Manaus, between December 1975 and May 1977. The species here described belong to a group of the genus so far known only from southern Brazil. The apparent absence near Manaus of the northern South American genus Meinertellus Silvestri is notable.
\end{abstract}

Neomachilellus adisi, sp. $\mathrm{n}$. (Figures 1A, 2, 3)

Maximum observed body length $12 \mathrm{~mm}$; maximum length or antennae $18 \mathrm{~mm}$, of terminal filament $14 \mathrm{~mm}$. Color of body light yellow; hypodermal pigment on head, mouthparts, antennae and legs. Color pattern formed by scales, unknown.

Head with $1+1$ pigment spots between ocelli and $1+1$ spots behind ocelli (figs. $1 \mathrm{~A}$, 3D). Color pattern of eyes (fig. 2A) consisting of three dark, curved stripes, their curvature parallel to that of anterior margin of eyes; uppermost dark stripe wider than the two others. Eyes approximately as long as wide, their line of contact equal to five sixth of their length. Ocelli (figs. 1A, 3D) only slightly shorter than anterior border of eyes, narrowly sole-shaped. Head capsule without secondary sexual scharacters. Antennae longer than body.
Scapus with pigment arranged as shown in figure $1 \mathrm{~A}$, characterized by elongate parallel-sided marking on outer surface. Flagellum light brown, with intermediate jointlets slightly but distinctly darker than chains (fig. 3E). Pigmentation of mandibles as shown in figure 2C. Maxillary palpi as shown in figures $2 E$, $3 \mathrm{~A}$, their pigment pattern characterized by narrow longitudinal dark mark on second article with field of short, semierect hairs (fig. 1J); remaining articles without special features; seventh as long as penultimate. Labial palpi narrowly bordered with pigment along anterior surface (figs. 2B, 3F). Terminal article of labial palp strongly widened in both sexes, almost twice as wide as long in male.

Pigmentation of legs as shown in figures $2 F, G ; 3 B, C$, characterized by elongate narrow marking on tibiae of all legs, although in some cases less developed on hind legs (fig. 3C). Femora and tibiae without spine-like setae, although some present on tarsi. Underside of hind tibiae with very numerous short, simple setae (fig. 2I).

Stylets of ninth abdominal segment of male as long as coxite (fig. $2 \mathrm{H}$ ), in female three fourths as long as coxite. Distal spine of stylet $V$ one half as long as stylet (fig. $3 G$ ), distal spine of stylet IX one fourth as long as stylet (fig. $2 \mathrm{H}$ ).

Apical portion of penis as illustrated (fig. $2 \mathrm{~K})$. Ovipositor attaining level of terminal spine of stylet IX. Gonapophyses consisting of 68-75 articles, their chaetotaxy (fig. $3 \mathrm{H}$ ) as usual for the genus.

MATERIAL EXAMINED: Brazil: Amazônia: Tarumã Mirim, near Manaus, in tree-traps, J. Adis leg. (one male, holotype, one female,

$\left({ }^{*}\right)$ - The American Museum of Natural History, New York. 


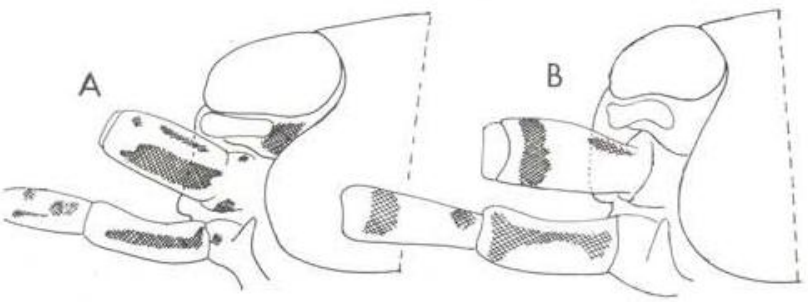

Fig. 1 - Head with scapus of antenna and with basal articles of maxillary palp, lateral view. - A. Neomachilellus adisi. B. Neomachilellus scandens Wygodzinsky del.

allotype, in the Instituto Nacional de Pesquisas da Amazônia (INPA); 10 paratypes and 32 additional specimens in the Instituto Nacional de Pesquisas da Amazônia (INPA) and in The American Museum of Natural History).

ETYMOLOGY: This species is named for its collector.

DISCUSSION: In the last published key to the species of Neomachilellus (Wygodzinsky, 1952), N. adisi would key out to $N$. ibiti Wygodzinsky, N. lenti Wygodzinsky and N. albuquerquei Wygodzinsky, all described from southern Brazil. N. adisi differs from ibiti by the presence of well developed pigment on the legs, absent in ibiti; by the much narrower distal article of the labial palp, in both sexes, and by the hypodermal pigment arranged in a dark, narrow longitudinal band on the second article of the maxiallry palp, very faint in ibiti. $N$. adisi can be distinguished from $N$. lenti by the relatively short apical spine of the stylets of urosternite $\mathrm{V}$, the spine being as long as the stylet itself in lenti; by the very short setae of the under surface of the hind tibiae, much longer in lenti; by the absence of a field of short spiniform setae on the apical portion of the second article of the maxillary palp of the male, present in lenti, and by the slightly but distinctly darkened intermediate jointlets of the flagellum of the antennae, concolorous with the chains in lenti. Finally, $N$. adisi can be distinguished from $N$. albuquerquei by the much more extensive pigment on the maxillary palpi; by the presence of pigment on the legs. almost absent in albuquerquei; by the very short setae on the under surface of the hind tibiae, much longer in albuquerquei, and by the smaller field of short semierect setae on the apex of the second article of the maxillary palp of the male.

\section{Neomachilellus scandens, sp. $\mathrm{n}$. (Figures 1B, 4, 5)}

Maximum observed body length $12 \mathrm{~mm}$; maximum length of antennae $17 \mathrm{~mm}$, of terminal filament $13 \mathrm{~mm}$. Color of body yellowish white; hypodermal pigment on head, mouthparts, antennae and legs. Color pattern formed by scales, unknown.

Head with $1+1$ pigment spots between ocelli (fig. 4F) and $1+1$ spots behind ocelli.

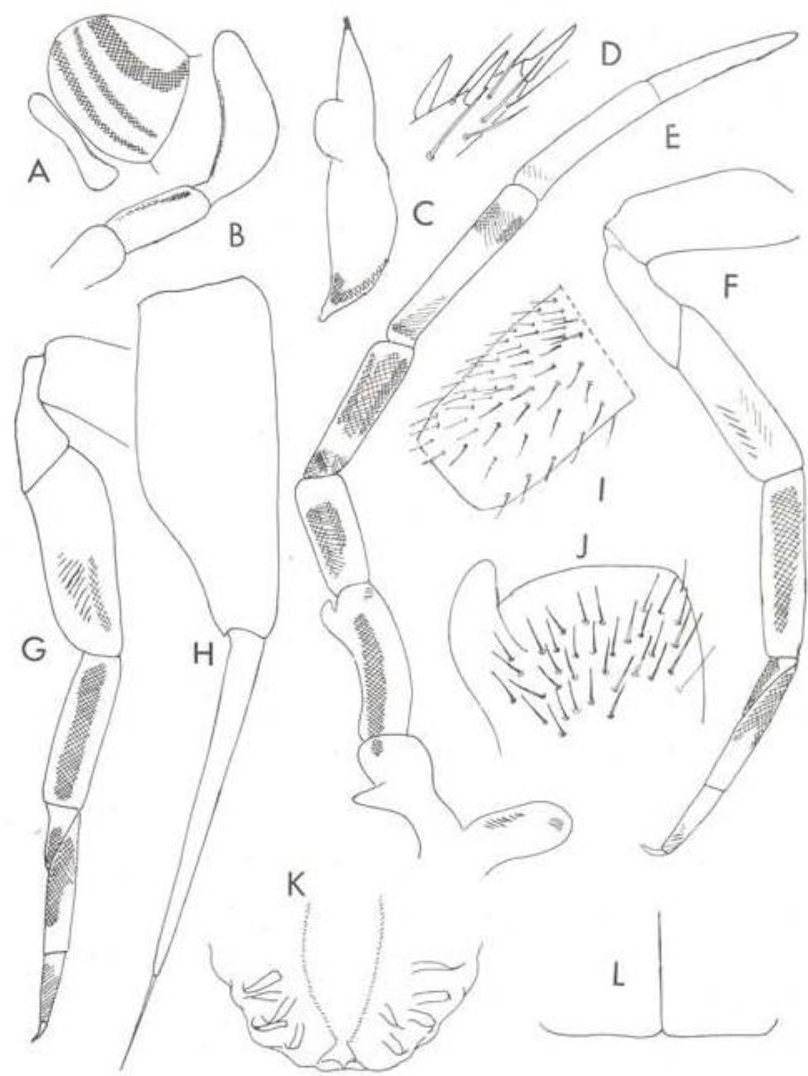

Fig. 2 - Neomachilellus adisi, male. - A. Eye and ocellus, sublateral view. B. Labial palp. C. Mandible. D. Apex of terminal article of maxillary palp. F. Hind leg. G. Fore leg. H. Coxite IX with stylet. 1. Apex of hind tibia. J. Apex of second article of maxillary palp. K. Apex of penis. L. Center of hind border of urosternite VIII. - Wygodzinsky del. 


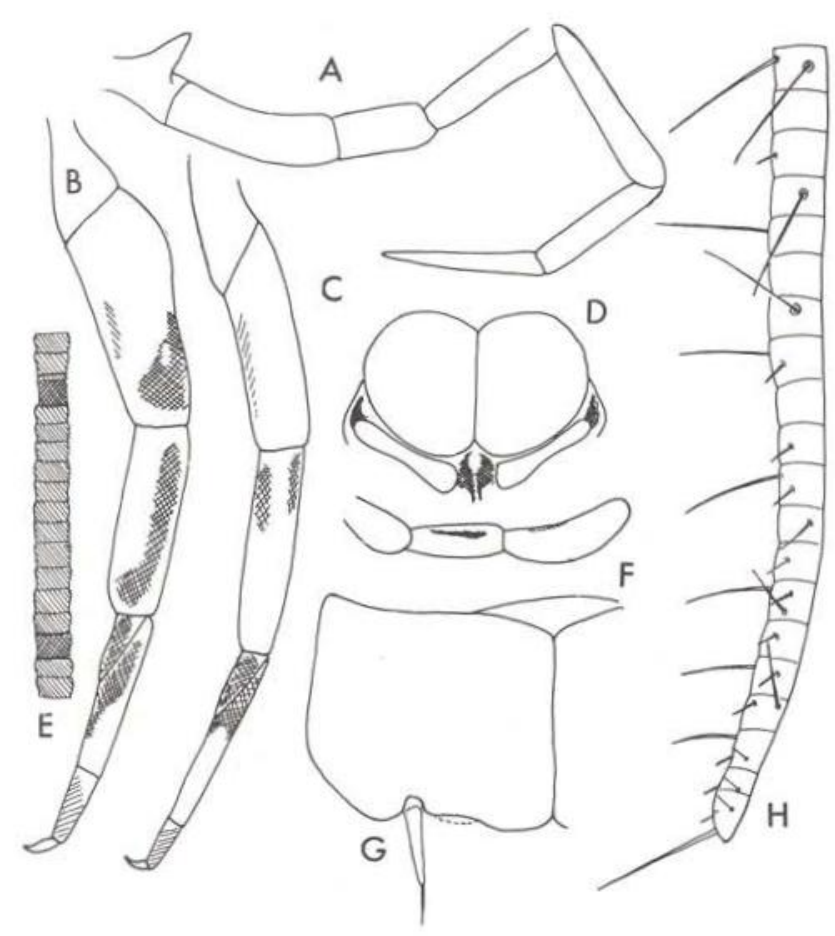

Fig. 3-Neomachilellus adisi, female. - A. Maxillary palp, outline only. B. Fore leg. C. Hind leg. D. Eyes and ocelli, front view. E. Portion of flagellum of antenna. F. Labial palp. G. Urosternite V. H. Distal area of anterior gonapophysis. - Wygodzinsky del.

Color pattern of eyes (fig. 4G) consisting of large diffuse spots (probably better defined in live specimens). Eyes (fig. 4E-G) slightly wider than long (length/width $=1 / 1.1$; their line of contact equal to three fifths their length. Ocelli only slightly shorter than anterior border of eyes, narrowly sole-shaped (figs. 1B, 4E, F). Head capsule not sexually dimorphic.

Antennae longer than body. Scapus with pigment arranged as in figure $1 \mathrm{~B}$, characterized by wide subapical, darkly pigmented, transverse marking. Flagellum light brown, with intermediate jointlets concolorous (fig. 4C) with chains or slightly darker. Pigment pattern of mandibles as shown in figure $5 \mathrm{H}$. Maxillary palpi as shown in figures $4 \mathrm{~A}, 5 \mathrm{~A}$, their pigment pattern characterized by hourglass-shaped, in some cases interrupted dark marking on second article (figs. 1B, 4A, 5A). Second article of palp of male with slightly sclerotized process beset with several long setae (fig. $4 \mathrm{~J})$; inner surface of apex of article only with scattered hairs, specialized setae absent. Remaining articles without special features, seventh as long as penultimate. Labial palpi narrowly bordered with pigment along anterior surface (figs. 4D, 5G). Terminal article of labial palp strongly widened in both sexes, almost twice as long as wide in male.

Pigmentation of legs as shown in figure $5 B, C$, similar in both sexes, characterized by wide extension of pigment on tibiae, especially on fore legs. Femora and tibiae without spinelike setae, aithough some present on tarsi. Under surface of posterior tibiae with dense, slender, medium-sized setae (fig. 41).

Stylets of ninth segment of male six seventh as long as coxite, in female two thirds as long as coxite. Distal spine of styles $\mathrm{V}$

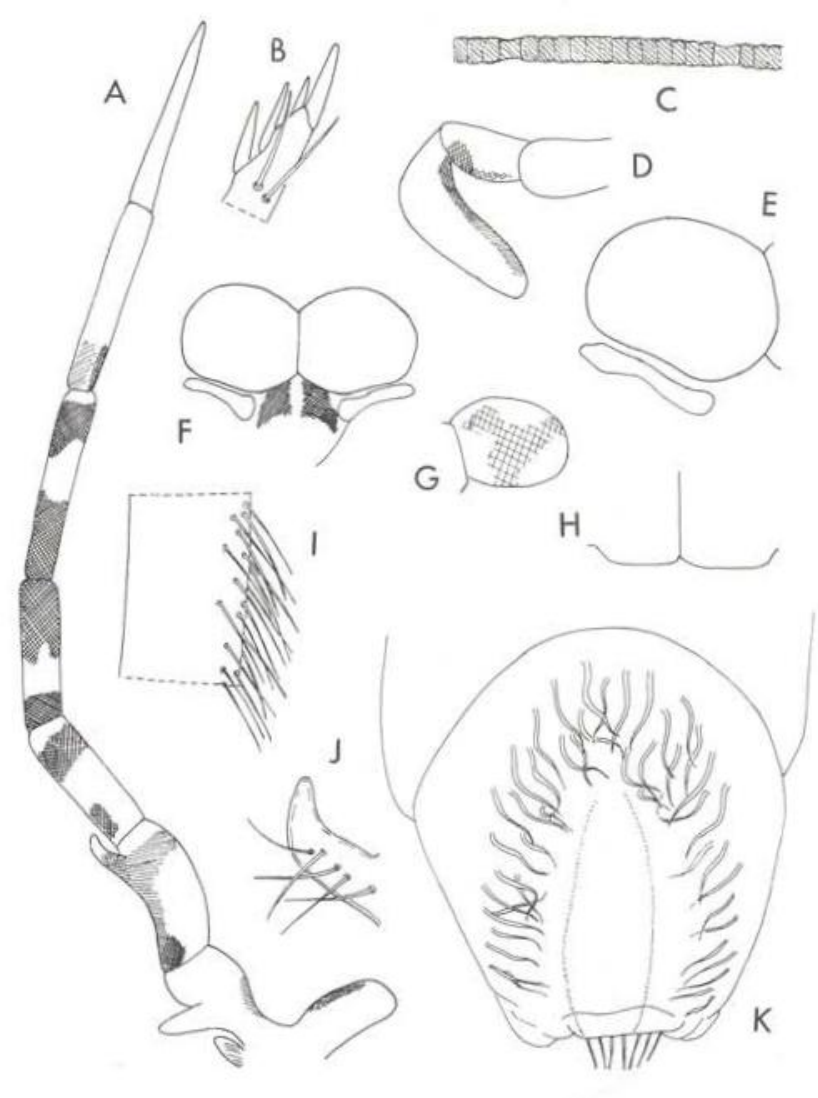

Fig. 4 - Neomachilellus scandens, male. - A. Maxillary palp. B. Apex of terminal article of maxillary palp. C. Portion of flagellum. D. Labial palp. E. Eye and ocellus, sublateral view. F. Eyes and ocelli, front view. G. Eye with color pattern, schematic. H Center of urosternite VIII. I. Setae of under surface of hind tibia. J. Hook-shaped process of second article of maxillary palp. K. Distal portion of penis. - Wygodzinsky del. 
(fig. 5F) two thirds as long as stylet; distal spine of stylet IX one half as long as stylet (fig. 5E).

Penis as illustrated (fig. 4K). Ovipositor attaining or slightly surpassing level of apex of terminal spine of stylets IX. Gonapophyses consisting of 55-60 articles, their chaetotaxy (fig. 5D) as usual for the genus.

MATERIAL EXAMINED: Brazil: Amazônia: Tarumã Mirim, near Manaus, in tree traps, J. Adis leg. (one male, holotype, one female, allotype, in the Instituto Nacional de Pesquisas da Amazônia (INPA) Manaus; 11 paratypes and 42 additional specimens in the Instituto Nacional de Pesquisas da Amazônia (INPA) and The American Museum of Natural History, New York).

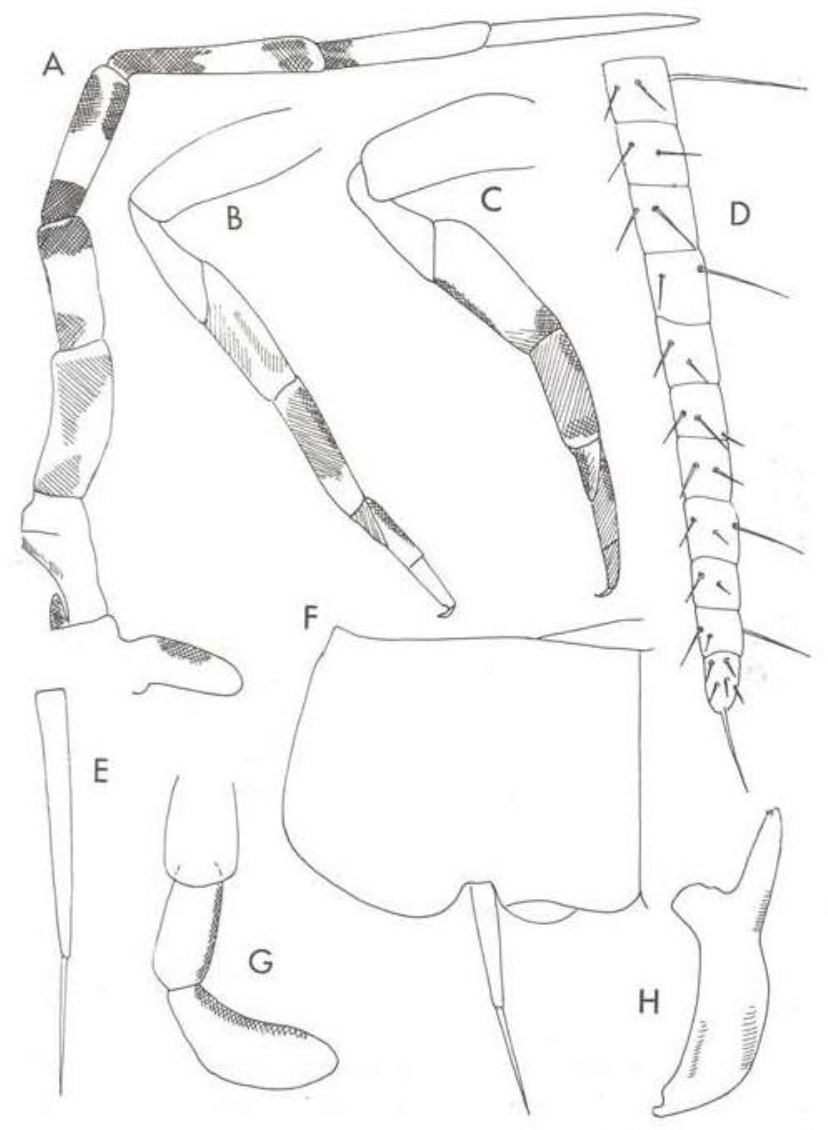

Fig. 5- Neomachilellus scandens, female. - A. Maxillary palp. B. Hind leg. C. Fore leg. D. Terminal portion of anterior gonapophysis. E. Stylet IX. F. Portion of urosternite V. G. Labial palp. H. Mandible. - Wygodzinsky del.
ETYMoLogy: From the Latin scando, climb, in allusion to the arboreal way of life of the species.

DISCussion: Neomachilellus scandens also keys out to $N$. ibiti, N. lenti and $N$. albuquerquei. N. scandens can be distinguished from ibiti by the relative length of the terminal article of the maxillary palp, equal in length to the penultimate article in scandens but distinctly shorter than the penultimate in ibiti, and by the apical spine of stylet V, about two thirds as long as the stylet proper in scandens and much shorter in ibiti. N. scandens differs from $N$. lenti by the absence, in the male, of a group of short spiniform setae on the apex of the second article of the maxillary palp, present in lenti, and by the relative size of the terminal article of the maxillary palp of both sexes, as long as the penultimate in scandens but much shorter than the penultimate in lenti. Finally, N. scandens is distinguished from $N$. albuquerquei by the apical spine of the stylets $\mathrm{V}$, two thirds as long as the stylet proper in scandens but only about half as long as the stylet in albuquerquei. In albuquerquei, the terminal article of the maxillary palp is much shorter than the penultimate, but about as long as the penultimate in scandens. Conspicuous hypodermal pigment is present on articles I-IV of the maxillary palp in scandens, but only on articles I-IV in albuquerquei.

Neomachilellus adisi and N. scandens are occasionally collected together and are clearly sympatric in the Manaus area. The two species can be distinguished as follows:

1. Eye pattern consisting of transverse stripes (fig. 2A); pigment of scapus forming large longitudinal band (fig. 1A); second article of maxillary palp of male with pigment arranged in shape of longitudinal stripe (figs. 1A, 2E); fore tibia with pigment arranged in longitudinal stripe (fig. 2G); apical spine of stylet proper (fig. 3G); terminal spine of stylet IX one fourth as long as stylet proper (fig. $2 \mathrm{H}$ ) ..... adisi

- Eye pattern consisting of large diffuse spots. (fig. 4G); pigment of scapus forming 
large subapical annulus (fig. 1B); second article of maxillary palp of male with pigment arranged in hourglass-shaped spot (figs. 1B, 5A); fore tibia almost entirely

\section{Sumário}

Sẳo descritas duas espécies novas de Microcoryphia, Neomachilellas adisi e $\mathbf{N}$. Scandens que ocorrem nos igapós perto de Manaus. Foram coletadas em armadilhas colocadas nas árvores. Essas novas espécies são comparadas com outras espécies do gênero que, até este relato, era apenas conhecido do sul do Brasil. pigmented (fig. 5C); apical spine of stylet $\mathrm{V}$ two thirds as long as stylet proper (fig. $5 \mathrm{~F}$ ); terminal spine of stylet IX one half as long as stylet proper (fig. 5E) .. scandens

\section{BIBLIOGRAFIA CITADA}

ADIS, JOACHIM

1977 - Programa mínimo para análise de ecossistemas: Artropoder terrestres em florestas inundáveis da Amazônia Central. Acta Amazonica $7(2): 223-229$

WYGODZINSKY, PEDRO

1952 - Acta Zool. Lilloana, 11 : 443-446.

(Aceito para publicaçăo em 10/05/78) 